\title{
PENGENDALIAN KUALITAS PRODUK REFINED BLEACHED AND DEODORIZED PALM KERNEL OIL DI PT KUALA LUMPUR KEPONG DUMAI
}

\author{
Junior Talieris Sarumaha ${ }^{(1)}$, \\ Wetri Febrina $^{(2)}$ dan Julanos \\ (3) \\ ${ }^{1)}$ Program Studi Teknik Industri, \\ Sekolah Tinggi Teknologi Dumai \\ Jl. Utama Karya Bukit Batrem II \\ Email: \\ juniortalierissarumaha16@gmail.com; \\ Wetri.febrina@gmail.com; \\ julanos279@gmail.com
}

\begin{abstract}
ABSTRAK
Kualitas merupakan salah satu faktor penting dalam aktivitas produksi. Hal ini menuntut perusahaan untuk tetap menjaga kualitas produk yang diproduksinya sehingga produknya dapat diterima konsumen serta mampu bersaing di pasar. PT KLK Dumai merupakan perusahaan yang bergerak di bidang pengolahan Crude Palm Kernel Oil (CPKO). Perusahaan ini masih mempunyai permasalahan pada mutu Refined Bleached And Deodorized Palm Kernel Oil (RBDPKO) dimana produk tidak memenuhi parameter yang telah ditentukan yang disebabkan oleh beberapa faktor. Metode yang digunakan dalam penelitian ini adalah adalah metode Six Sigma. Metode ini terbagi atas 5 tahapan, yaitu Define, Measure, Analyze, Improvement dan Control (DMIAC). Parameter produk dengan persentase cacat tertinggi adalah parameter FFA yaitu 7\%, kemudian parameter colour yaitu 5\% dan yang terendah adalah parameter Moisture yaitu $1 \%$. Pengujian kapabilitas proses diketahui nilai $\mathrm{C}_{\mathrm{pk}}$ FFA 1,62>1, nilai $\mathrm{C}_{\mathrm{pk}}$ Moisture 2,97>1 dan nilai $\mathrm{C}_{\mathrm{pk}}$ Colour 1,27 > 1 hal ini menunjukkan bahwa parameter FFA, Moisture dan Colour memenuhi spesifikasi akan tetapi harus dilakukan pemantauan.Faktor yang mempengaruhi kualitas RBDPKO terdiri atas manusia, metode, mesin, material dan lingkungan. Untuk mengatasi permasalahan pada parameter mutu Produk RBDPKO penulis menerapkan metode 5W-1H.
\end{abstract}

Kata-kunci: Kualitas, Parameter, RBDPKO, Six Sigma.

\begin{abstract}
Quality is one of the key factors in production activity. This requires companies to keep the quality of their products so that they are acceptable to the costumer and able to complete in the market. PT KLK Dumai is a company engaged in the processing of Crude Palm Kernel Oil (CPKO). This company still has problems with the quality of Refined Bleached And Deodorized Palm Kernel Oil (RBDPKO) where the product does not meet the specified parameters caused by several factors. This study was using Six Sigma method.This method divided into five stages, namely Define, Measure, Analyze, Improvement and Control (DMIAC). Product parameters from the highest to the lowest are FFA with 7\%, Colour is 5\%, and then Moisture is 1\%. Parameter process capability with $C_{p k}$ FFA 1,62 > 1, $C_{p k}$ Moisture 2,97 > 1 and $C_{p k}$ Colour 1,27> 1 which means the process meets the specs, however it needs monitoring. The factors affecting the quality of RBDPKO are made of human beings, methods, machines, materials, and the environment. To address the issue of quality parameters for RBDPKO products, the writer uses $5 W-1 H$.
\end{abstract}

Key Words: : Quality, Parameter, RBDPKO, Six Sigma 


\section{Pendahuluan}

Kualitas merupakan salah satu faktor penting dalam aktivitas produksi. Hal ini menuntut perusahaan untuk tetap menjaga kualitas produknya sehingga dapat diterima konsumen serta mampu bersaing di pasar. Pengendalian kualitas yang baik akan memberikan dampak terhadap mutu produk yang di hasilkan. Kualitas dari produk yang dihasilkan oleh perusahaan ditentukan berdasarkan ukuran standar operasional perusahaan. Standar kualitas yang dimaksud adalah bahan baku, proses produksi dan produk jadi. Pengendalian kualitas sepenuhnya harus diterapkan dari proses awal sampai produk jadi dan disesuaikan dengan standar mutu yang ditetapkan. Meskipun proses produksi terlaksana dengan baik, namun pada kenyataannya masih ditemukan masih ditemukan kesalahan-kesalahan dimana kualitas produk yang dihasilkan tidak sesuai dengan standar mutu atau produk yang dihasilkan cacat seperti yang terjadi di PT KLK Dumai.

PT KLK Dumai merupakan perusahaan yang bergerak di bidang pengolahan Crude Palm Kernel Oil (CPKO). Perusahaan ini masih mempunyai permasalahan pada mutu Refined Bleached And Deodorized Palm Kernel Oil (RBDPKO) dimana produk tidak memenuhi parameter yang telah ditentukan yang disebabkan oleh berbagai macam faktor. Banyaknya minyak yang tidak sesuai spesifikasi dapat meningkatkan biaya dan waktu produksi yang besar, hal ini tentunya dapat merugikan perusahaan oleh karena itu perlu dilakuan pengendalian kualitas untuk meminimalisir produk gagal. Metode peningkatan kualitas salah satunya adalah metode Six Sigma.

Berdasarkan permasalahan diatas sehingga Penulis mengambil judul Pengendalian Kualitas Produk Refined Bleached And Deodorized Palm Kernel Oil di PT KLK Dumai.

\section{Metode Penelitian}

Data yang digunakan dalam penelitian ini adalah Data primer merupakan data yang diperoleh dari divisi produksi dan pihak laboratorium PT KLK Dumai dengan menggunakan kuesioner dengan jumlah responden sebanyak 12 orang, wawancara tentang proses produksi dan Sampel produk RBDPKO mulai dari tanggal 1 Juli -31 Juli 2021. Selanjutnya dilakukan analisis data meliputi beberapa langkah sebagai berikut:

1. Define (Definisi)

Merupakan langkah awal dalam tahap perbaikan six sigma. Langkah yang akan dilakukan adalah sebagai berikut:

a. Proses mapping dan mendefinisikan proses kunci, tahap ini akan menyajikan urutan proses produksi dan menentukan proses kunci yang banyak mengakibatkan defect dan berpengaruh critical to quality.

b. Identifikasi masalah, pada proses pengedentifikasian masalah akan menguraikan macam-macam defect yang dapat mengakibatkan terjadinya repair/rework karena tidak sesuai dengan spesifikasi standart.

c. Penetapan tujuan, dalam tahap definisi selanjutnya adalah penetapan tujuan yang akan dijelaskan tujuan dari perbaikan six sigma.

2. Measure (Pengukuran)

Langkah kedua adalah pengukuran (Measure) yang akan yang akan menyajikan beberapa tahap berikut: 
a. Penetapan CTQ (Critical to Quality), pada tahap ini akan menentukan karakteristik kebutuhan spesifik pelanggan yang telah digambarkan dalam standart kualitas perusahaan. Standart kualitas perusahaan mengacu pada Code ASME (American Society of Mechanical Engineering).

b. Mengetahui urutan CTQ (Critical to Quality), setelah menetapkan CTQ (Critical to Quality) tahap selanjutnya adalah mengetahui urutannya berdasarkan tingkat jumlah kecacatannya. Pada tahap ini dapat menggunakan diagram pareto sebgai alat untuk mengidentifikasinya.

c. Pengukuran stabilitas proses, tahap pengukuran stabilitas proses bertujuan mengetahui tingkat terkendali atau tidanya suatu proses yang dapat diketahui melalui grafik kontrol $p$. Sebelum membuat grafik kontrol $p$ harus menentukan terlebih dahulu nilai rata-rata kecacatan $(p)$ atau CL (Central Line), LCL (Lower Control Limit) dan UCL (Upper Cotrol Limit).

d. Pengukuran kapasitas proses, bertujuan untuk mengetahui sejauh mana suatu produk dapat memenuhi kebutuhan spesifik pelanggan, sebelum produk itu diserahkan kepada pelanggan. Dalam pengukuran base line kinerja digunakan satuan pengukuran DPMO (Defect Per Million Opportunity) untuk menentukan tingkat sigma. Dalam menentukan kapabilitas proses antara data variabel dengan data atribut berbeda. Suatu proses dikatakan baik atau mampu (capable) jika mempunyai nilai indeks kapabilitas proses (Cp) dan Cpk lebih besar dari 1 (Budiarto, 2010 dalam Wahyuni, dkk, 2015).

3. Analysis (Analisis)

Tahap Analyze pada DMAIC berfungsi untuk memberikan masukan atas prioritas dalam upaya penanggulangan penyebab masalah.

a. Penyebab terjadinya defect (secara teknik), bertujuan untuk mengetahui penyebab teknis terjadinya cacat las dapat dilakukan dengan menggali informasi seorang welding inspector (WI). Welding inspector adalah seorang instruktur pengelasan yang selalu mengawasi proses pengelasan dan mengkonfirmasikan dengan WPS (Welding Procedure Specification) apakah sesuai dengan prosedur yang diijinkan atau belum serta menginspeksi hasil pengelasan.

b. Penelusuran akar penyebab masalah, penetapan akar penyebab masalah dapat dilakukan dengan menggunakan diagram fish bone melalui pandangan 5 faktor yaitu manusia, metode, mesin, material dan lingkungan. Dengan fish bone diagram akan lebih mempermudah proses analisa permasalahan. Setelah itu dilakukan analisa untuk mendapatkan akar penyebab kecacatan.

4. Improvement (perbaikan)

Pada tahap ini akan menyajikan usulan perbaikan dan pengendalian yang didapatkan dari interpretasi hasil. Setelah akar dari masalah penyebab kualitas teridentifikasi, maka perlu dilakukan penetapan rencana tindakan untuk melaksanakan peningkatan kualitas. Dalam upaya memberikan usulan perbaikan, akan dilakukan melalui konsep bertanya 5W-1H yaitu What (apa), Why (mengapa), Where (dimana), When (kapan atau bilamana), Who (siapa) dan How (bagaimana). Selain itu juga akan diberikan usulan secara teknis dalam upaya perbaikan penyebab potensial kegagalan. 


\section{Hasil dan Pembahasan}

Data yang diambil dalam penelitian ini berdasarkan parameter tes FFA, Moisture, Colour (R/Y) dengan melakukan analisa terhadap minyak yang diproduksi untuk mengetahui kualitas minyak.

\section{Pengukuran Capability Process}

Pengukuran Capability Process (Kapabilitas Proses) bertujuan untuk mengetahui tingkat kemampuan proses dalam memenuhi batas spesifikasi Critical To Quality yang telah ditentukan.

\section{Pengukuran Capability Process FFA}

Indeks kapabilitas proses $(\mathrm{Cp})$ diartikan sebagai rasio lebar spesifikasi terhadap toleransi alami. Pengukuran kapabilitas proses parameter FFA dapat dilihat pada Gambar 1.

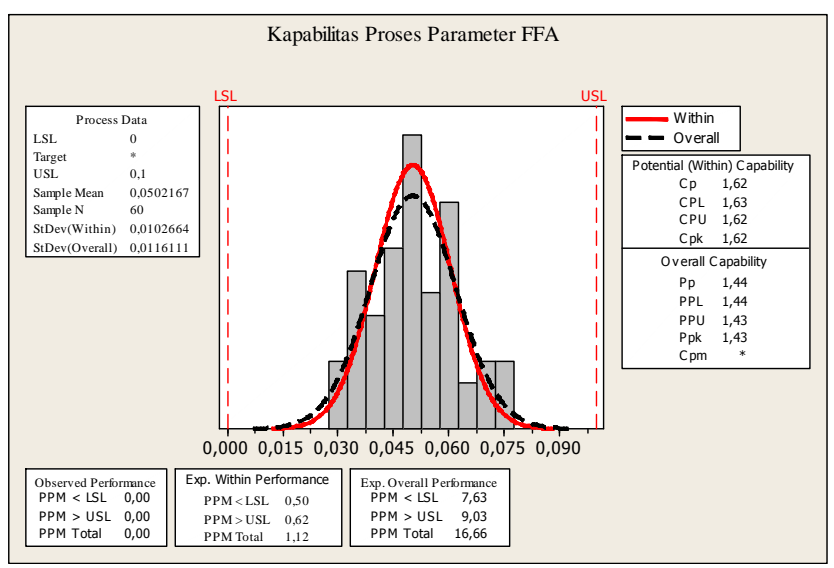

Gambar 1. Capability process FFA

Gambar 1 menunjukkan hasil pengukuran kapabilitas proses FFA, diketahui nilai $\mathrm{C}_{\mathrm{pk}} 1,62>1$ hal ini menunjukkan bahwa proses memenuhi spesifikasi akan tertapi harus dilakukan pemantauan.

\section{Pengukuran Capability Process Moisture}

Indeks kapabilitas proses (Cp) diartikan sebagai rasio lebar spesifikasi terhadap toleransi alami proses. Pengukuran kapabilitas proses dapat dilihat pada Gambar 2.

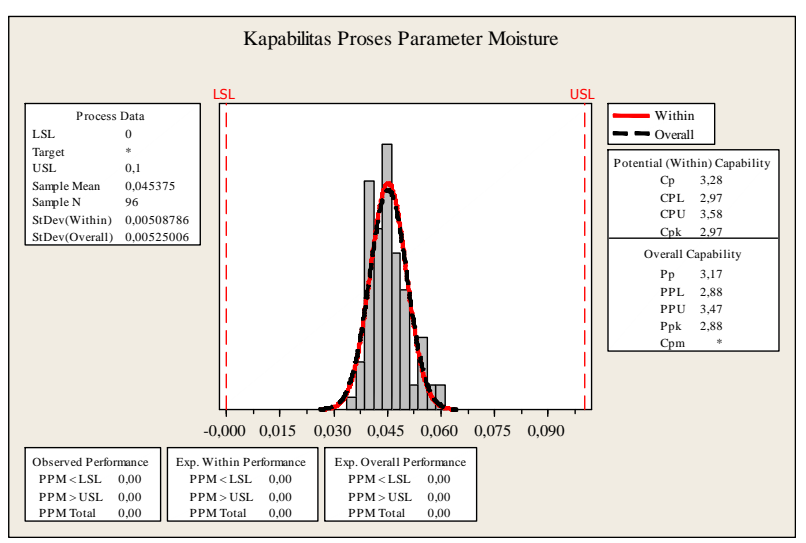

Gambar 2. Capability process moisture 
Gambar 2 merupakan hasil perhitungan indeks kapabilitas proses pada parameter Moisture diketahui nilai $\mathrm{C}_{\mathrm{pk}} 2,97>1$, hal ini menunjukkan bahwa proses memenuhi spesifikasi akan tetapi harus dilakukan pemantauan.

\section{Pengukuran Capability Process Colour}

Indeks kapabilitas proses (Cp) diartikan sebagai rasio lebar spesifikasi terhadap toleransi alami proses. Pengukuran kapabilitas proses dapat dilihat pada Gambar 3.

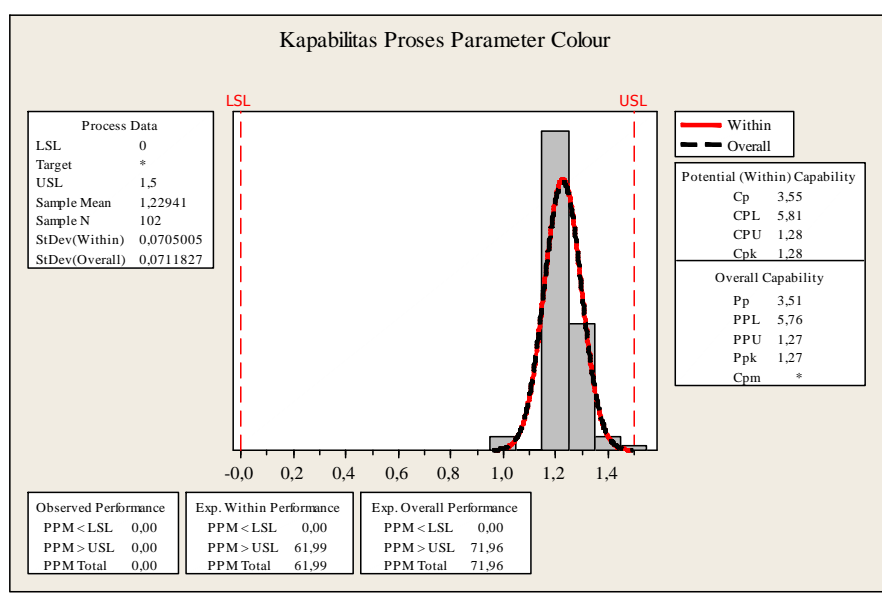

Gambar 3. Capability Process Colour

Gambar 3 menunjukkan hasil pengukuran kapabilitas proses Colour, diketahui nilai $\mathrm{C}_{\mathrm{pk}} 1,27>1$ hal ini menunjukkan bahwa proses memenuhi spesifikasi akan tetapi harus dilakukan pemantauan.

\section{Diagram Pareto Parameter RBDPKO}

Diagram pareto berfungsi untuk mempermudah analisa terhadap parameter mutu yang perlu mendapatkan prioritas perbaikan dan pengendalian mutu. Berikut ini adalah persentase cacat dari setiap parameter produk yang meliputi FFA, Moisture dan Colour dapat dilihat pada Gambar 4.

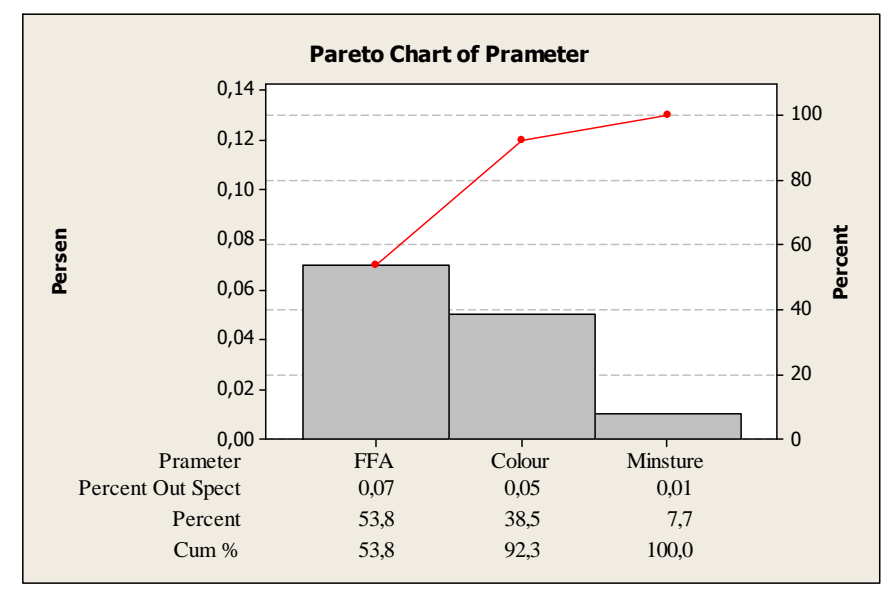

Gambar 4. Persentase Produk Cacat RBDPKO

Gambar 4. merupakan diagram yang menunjukkan persentase parameter produk cacat. FFA merupakan parameter produk yang memiliki tingkat cacat tertinggi yaitu 7\% 
dan parameter colour yaitu 5\% sedangkan parameter moisture merupakan yang terrendah dengan persentase cacat $1 \%$

\section{Penelusuran Akar Penyebab Terjadinya FFA, Colour dan Moisture Out Spect Menggunakan Fish Bone Diagram}

Parameter FFA merupakan parameter dengan persentase cacat tertinggi yaitu $52,9 \%$, sehingga perlu dilakukan proses perbaikan. Untuk mempermudah proses mengetahui penyebab kegagalan produk digunakan alat bantu diagram sebab-akibat. Dari hasil quesioner terbuka yang dilakukan terhadap karyawan PT KLK Dumai dengan jumlah 12 orang responden, FFA merupakan parameter dengan persentase cacat yaitu $7 \%$, sehingga perlu dilakukan proses perbaikan adapun yang menjadi penyebab kecacatan produk yang disebabkan oleh FFA dapat dilihat pada Gambar 5.

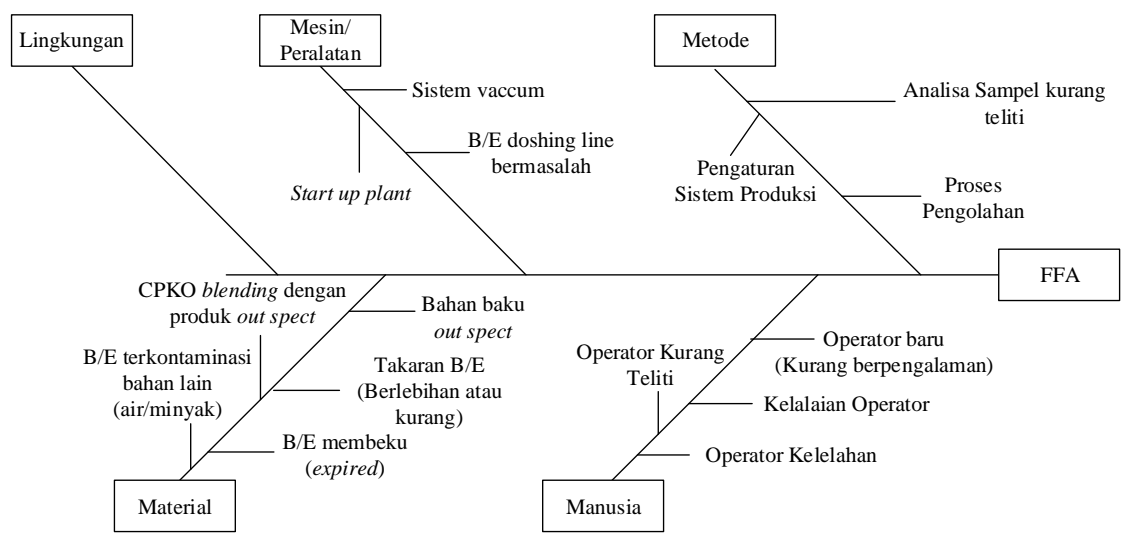

Gambar 5. Diagram Fish Bone FFA

Colour merupakan parameter dengan persentase cacat yaitu 5\%, sehingga perlu dilakukan proses perbaikan. Analisa diagram sebab-akibat parameter colour dapat dilihat pada Gambar 6.

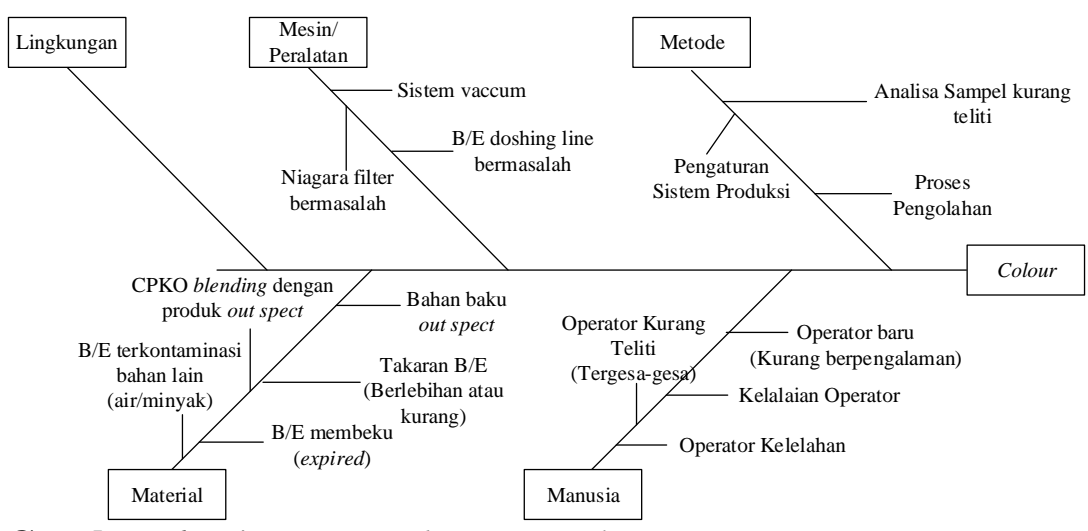

Gambar 6. Diagram Fish Bone Colour

Moisture merupakan parameter dengan persentase cacat yaitu 1\%, merupakan parameter cacat paling rendah namun harus tertap dilakukan pamantauan. Analisa diagram sebab-akibat parameter colour dapat dilihat pada Gambar 4.10. 


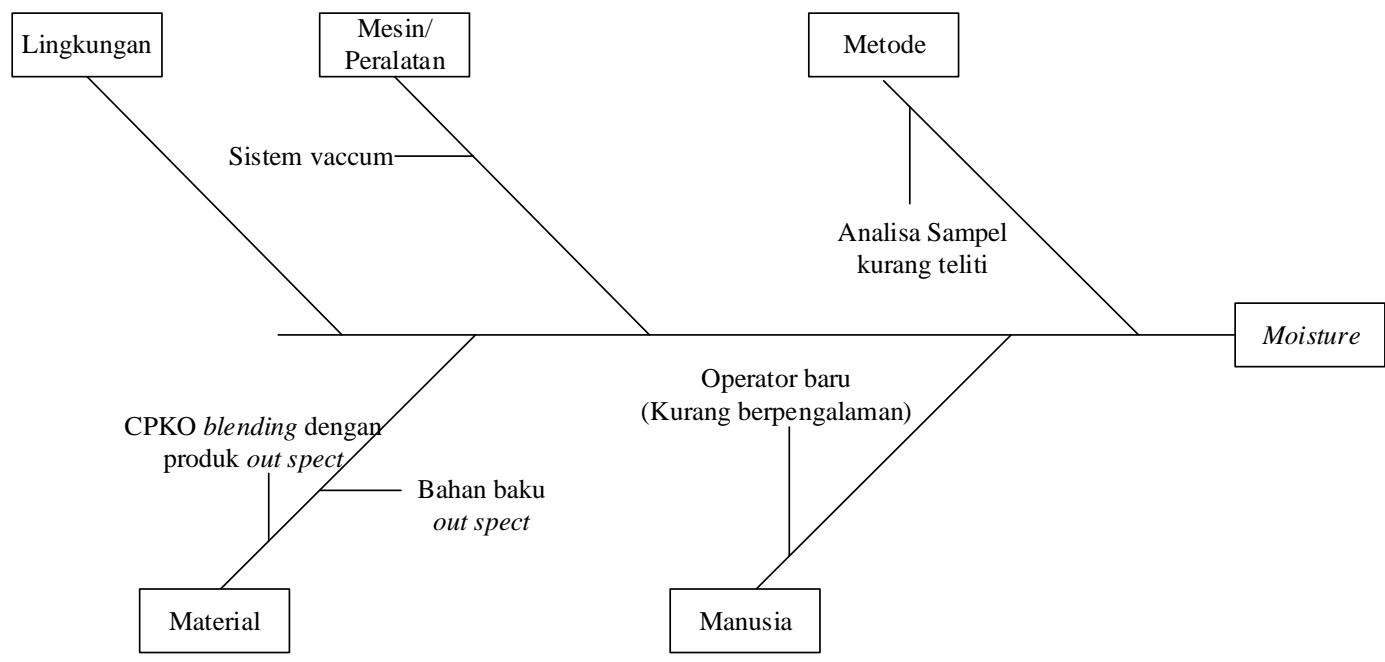

Gambar 7. Diagram Fish Bone Moisture

\section{Tahap Perbaikan dengan Metode 5W-1H}

Tahap perbaikan proses bertujuan untuk mengurangi penyebab terjadinya produk cacat RBDPKO. Proses perbaikan dilakukan dengan menggunakan metode 5W$1 \mathrm{H}$ adapun usulan tersebut dapat dilihat pada Tabel 1.

Tabel 1. Usulan Perbaikan Manajerial

\begin{tabular}{|c|c|c|}
\hline \multicolumn{2}{|c|}{$5 \mathrm{~W}-1 \mathrm{H}$} & Tindakan \\
\hline $\begin{array}{l}\text { Tujuan } \\
\text { Utama }\end{array}$ & $\begin{array}{l}\text { What } \\
\text { (Apa) }\end{array}$ & $\begin{array}{l}\text { 1. Perusahaan memiliki komitmen yang kuat untuk } \\
\text { melakukan perbaikan yang berkesinambungan. } \\
\text { 2. Memberikan motivasi terhadap karyawan produksi } \\
\text { memiliki perusahaan serta menumbuhkan rasa tanggung } \\
\text { jawab terhadap perkerjaan yaang diberikan. } \\
\text { 3. Memberikan pembekalan pengetahuan dasar tentang } \\
\text { proses pengolahan RBDPKO. } \\
\text { 4. Melakukan perwatan terhadap mesin produksi secara } \\
\text { berkesinambungan. }\end{array}$ \\
\hline $\begin{array}{c}\text { Alasan } \\
\text { Kegunaan }\end{array}$ & $\begin{array}{c}\text { Why } \\
\text { (Mengapa) }\end{array}$ & $\begin{array}{l}\text { 1. Menghasilkan produk tanpa prameter cacat tidak dapat } \\
\text { dilaksanakan satu kali saja namun harus } \\
\text { berkesinambungan. Hal ini didukung dengan adanya } \\
\text { komitmen dari karyawan maupun pihak manajemen. } \\
\text { 2. Karyawan atau pihak manajemen yang memiliki } \\
\text { motivasi yang tinggi dalam melakukan perbaikan yang } \\
\text { berkelanjutan akan melakukan pekerjaan dengan sangat } \\
\text { berhati-hati dan teliti sehingga mampu meminimalkan } \\
\text { terjadinya produk cacat. } \\
\text { 3. Menghasilkan produk yang baik didasarkan dari } \\
\text { pengetahuan dan pengalaman karyawan itu sendiri. } \\
\text { Dengan adanya ilmu pengetahuan dasar pada } \\
\text { pengolahan RBDPKO tentunya karyawan mampu } \\
\text { mengatasi permasalahan yang terjadi terhadap mutu } \\
\text { RBDPKO. }\end{array}$ \\
\hline
\end{tabular}


Tabel 1. Usulan Perbaikan Manajerial (Lanjutan)

\begin{tabular}{|c|c|c|}
\hline & & $\begin{array}{l}\text { 4. Mesin yang efesien akan menghasilkan produk yang } \\
\text { baik sehingga untuk menjaga produktivitas mesin harus } \\
\text { dilakukan perawatan rutin. }\end{array}$ \\
\hline Lokasi & $\begin{array}{l}\text { Where } \\
\text { (Dimana) }\end{array}$ & $\begin{array}{l}\text { Proses perbaikan di departemen produksi dan departemen } \\
\text { QC (Labor). }\end{array}$ \\
\hline Urutan & $\begin{array}{l}\text { When } \\
\text { (Bilamana) }\end{array}$ & $\begin{array}{l}\text { 1. Perbaikan dilakukan sesuai tahapan metode Six Sigma } \\
\text { DMAIC. } \\
\text { 2. Rencana tindakan perbaiakan sebaiknya dilakukan } \\
\text { secepatnya atau setelah diterima dan disetujui usulan ini } \\
\text { oleh perusahaan. }\end{array}$ \\
\hline Orang & $\begin{array}{l}\text { Who } \\
\text { (Siapa) }\end{array}$ & $\begin{array}{l}\text { 1. Top management bertanggung jawab sepenuhnya dalam } \\
\text { upaya proses perbaikan manajemen puncak memiliki } \\
\text { perhatian besar terhadap kesehatan perusahaan jangka } \\
\text { panjang } \\
\text { 2. Manager prduction dan jajaranya bertanggung jawab } \\
\text { dari setiap karyawan. Sebagai media penyampai adalah } \\
\text { foreman. } \\
\text { 3. Jajaran Departemen Produksi bekerjasama dengan } \\
\text { Departemen Quality Control untuk melakukan } \\
\text { pembekalan pengetahuan tentang pengolahan } \\
\text { RBDPKO. } \\
\text { 4. Manager produksi bertanggung jawab terhadap } \\
\text { penjadwalan pemeliharaan mesin. }\end{array}$ \\
\hline Metode & $\begin{array}{l}\text { How } \\
\text { (Bagaiman } \\
\text { a) }\end{array}$ & $\begin{array}{l}\text { 1. Top management mendukung sepenuhnya setiap } \\
\text { langkah perbaikan. } \\
\text { 2. Manajemen tengah harus komitmen melakuan perbaikan } \\
\text { 3. Karyawan, operator dan jajarannya melakukan } \\
\text { perbaikan dengan penuh tanggung jawab dan } \\
\text { kedisplinan yang tingggi } \\
\text { 4. Cara untuk menumbuhkan motivasi kerja terhadap } \\
\text { karyawan dapat dilakukan dengan: } \\
\text { a. Melakukan penilaian kinerja yang objektif terhadap } \\
\text { karyawan. Bagi karyawan yang memiliki kinerja } \\
\text { yang baik diberikan pengharggan agar dapat } \\
\text { momotivasi karyawan itu sendiri dan karyawan } \\
\text { lainnya. } \\
\text { bemberikan penghargaan kepada karyawan yang } \\
\text { memiliki kreatifitas yang tinggi } \\
\text { c. Memberikan pengarahan tentang aktivitas perbaikan } \\
\text { secara berulang-ulang kepada karyawan. } \\
\text { 5. Upaya pembekalan pengetahuan dasar } \\
\text { pengolahan RBDPKO dapat dilakukan dengan: } \\
\text { a. Memberikan pembekalan pengetahuan dasar kepada } \\
\text { karyawan secara rutin dan materi yang semakin } \\
\text { berkembang. }\end{array}$ \\
\hline
\end{tabular}


Tabel 1. Usulan perbaikan manajerial (Lanjutan)

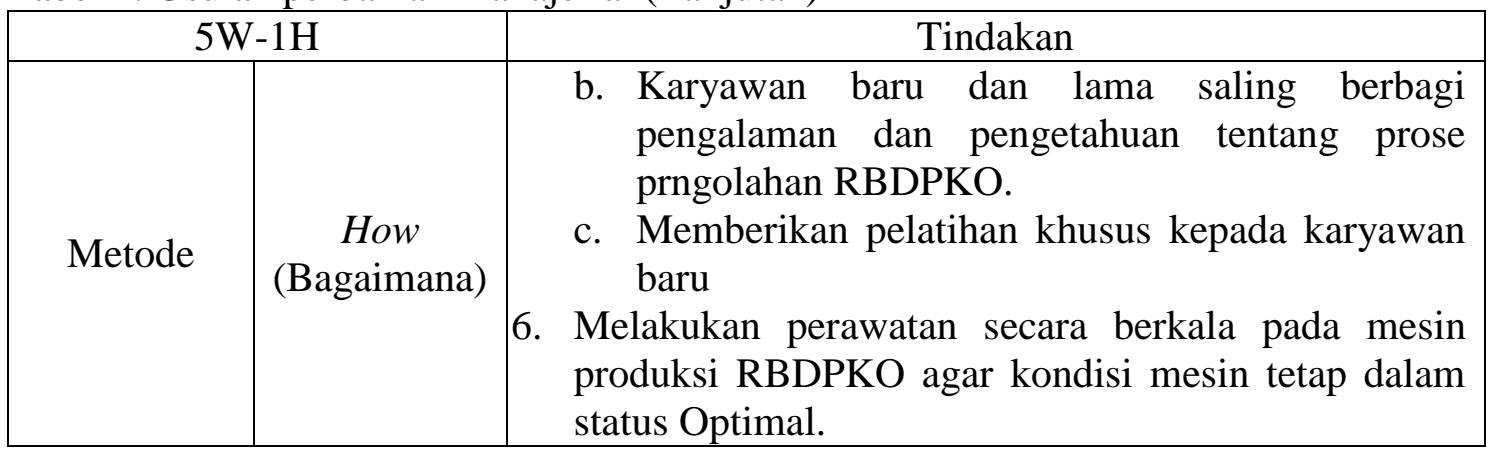

\section{Kesimpulan}

Pengendalian kualitas dengan metode six sigma DMAIC dapat disimpukan sebagai berikut:

1. Proses pelaksanaan pengendalian kualitas RBDPKO di PT KLK Dumai dinilai belum terlaksana dengan baik. Dari hasil perhitungan menunjukkan persen cacat dari masing-masing parameter yaitu: FFA dengan nilai $7 \%$ merupakan parameter cacat yang tertinggi, Colour dengan nilai 5\% merupakan parameter cacat tertinggi kedua dan Moisture dengan nilai 1\% merupakan parameter cacat yang paling rendah.

2. Faktor yang mempengaruhi kualitas produk RBDPKO di PT KLK Dumai didasarkan dari 5 faktor yaitu:

a. Manusia merupakan faktor yang paling penting dalam proses pengendalian kualitas,

b. Metode merupakan faktor penting yang berhubungan erat dengan faktor manusia karena dengan adanya metode kerja yang baik oleh manusia maka akan tercipta produk yang berkualitas,

c. Mesin/peralatan adalah faktor pendukung terjadinya proses produksi, Material atau bahan baku sangat mempengaruhi kualitas produk akhir dari perusahaan,

d. Lingkungan merupakan hal terpenting yang harus dimiliki perusahaan dengan terciptanya lingkungan kerja yang baik maka akan menghasilkan produk yang baik.

\section{Daftar Pustaka}

Ariani, Dorothea Wahyu, 2003. Manajemen Kualitas Pendekatan Sisi Kualitatif. Penerbit Ghalia Indonesia, Jakarta.

Ariani, Dorothea Wahyu, 2003. Pengendalian Kualitas Statistik, Penerbit Andi. Yogyakarta.

Gasperz, Vincent, 2003. Total Quality Management. Penerbit Vinchristo Publication, Jakarta.

Gasperz, Vincent, 2001. Metode Analisis Untuk Peningkatan Kualitas Penerbit Gramedia Pustaka Utama, Jakarta.

Grant, Eugene L dan Leavenworth Richard S,1998. Pengendalian Mutu Statis. Penerbit Erlangga, Jakarta.

Hendrawan, E., Susanto, H, V., Susanto, S, A, J., dan Raharjo, B., 2017, Analisa Kapabilitas Proses untuk Proses Injeksi dan Blow Moulding, Jurnal Rekayasa sistem dan Industri, Vol 4, No.1. 
Lestari, S., dan Junaidy, M, H., 2020, Pengendalian Kualitas Produk Compound At-807 di Plant Mixing Center Dengan Metode Six Sigma pada Perusahaan Ban di Jawa Barat, Jurnal Teknik, Vol. 9, No. 1, E-ISSN: 2581-0006

Novitasari, D, A., 2015, Analisis Kapabilitas Proses untuk Pengendalian Kualitas Produk Pembatas Buku Industri Rumahan, Jurnal EKBIS, Vol. XIV, No. 2

Rahayu, P., dan Supono, J., 2020, Analisis Pengendalian Kualitas Produk Menggunakan Metode Statistical Quality Control (SQC) Pada Divisi Curing Plant di P. Gajah Tunggal, Tbk, Jurnal Teknik, Vol 9, No. 1, E-ISSN: 25810006

Rosindasari, A., dan Iftadi, I., 2020, Implementasi Six Sigma dalam Pengendalian Kualitas Produk Refined Bleached Deodorized Palm Oil, Jurnal INTECH Teknik Industri Universitas Serang Raya Vol. 6, No. 2, E-ISSN: 2655-2655

Setiawati, K, L., Striawan I, K., dan Yoga I, G, S., 2020, Analisa Pengendalian Kualitas Menggunakan Metode Six Sigma pada Produk Roti Tawar di PT Ital Fran's Multindo Food Industries Cabang Bali, Jurnal Rekayasa dan Manajemen Agroindustri, Vol. 8, No. 4, ISSN:2503-488

Supriadi, A., Daonil, dan Zulkarnaen, I., 2020, Analisis Pengendalian Mutu pada Proses Produksi Pembuatan KecapMenggunakan Metode Fault Tree Analysis (FTA) dan Metode Failure Mode Efect Analysis (FMEA), Journal of Industrial and Engineering Sistem (JIES), Vol. 1, No. 1, E-ISSN: 2722-7979

Tannady, H., 2015, Pengendalian Kualitas, Graha Ilmu, Yogyakarta.

Wahayuni, H, C., Sulistoyowati, W., dan Khamim, M., 2015, Pengendalian Kualitas, Graha Ilmu, Yokyakarta 